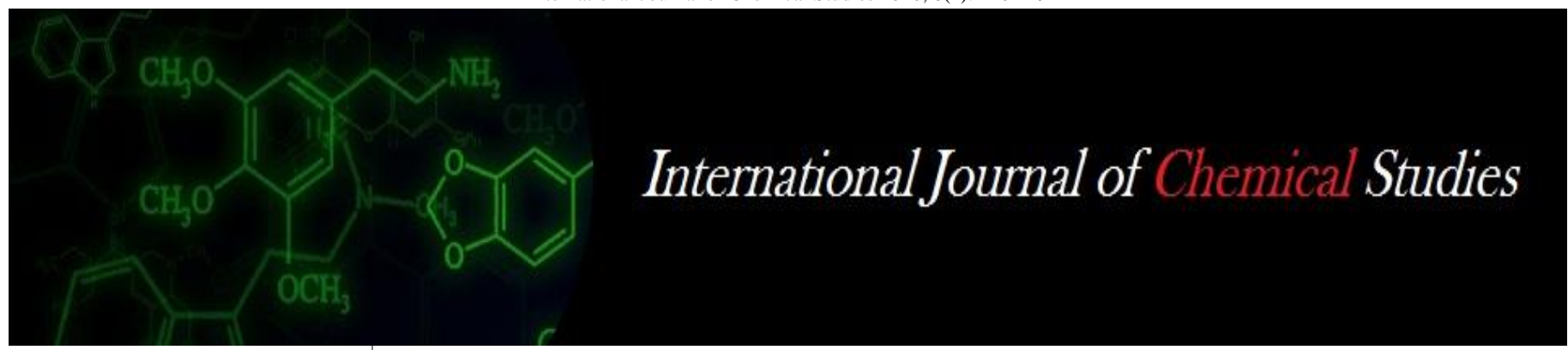

P-ISSN: 2349-8528

E-ISSN: 2321-4902

www.chemijournal.com

IJCS 2020; 8(2): 426-429

(C) 2020 IJCS

Received: 01-01-2020

Accepted: 03-02-2020

\section{PP Salvi}

Ph.D. Student, Department of Plant Pathology, College of Agriculture Dapoli, DBSKKV, Dapoli, Maharashtra, India

\section{PG Borkar}

Associate Professor, Department of Plant Pathology, College of Agriculture Dapoli, DBSKKV, Dapoli, Maharashtra, India

\section{JJ Kadam}

Associate Professor, Department of Plant Pathology, College of Agriculture Dapoli, DBSKKV, Dapoli, Maharashtra, India

\section{MS Joshi}

Head and Professor, Department of Plant Pathology, College of Agriculture Dapoli, DBSKKV, Dapoli, Maharashtra, India

\section{Corresponding Author:} PP Salvi

Ph.D. Student, Department of Plant Pathology, College of Agriculture Dapoli, DBSKKV, Dapoli, Maharashtra, India

\section{Management of bacterial wilt of brinjal incited by Ralstonia solanacearum}

\author{
PP Salvi, PG Borkar, JJ Kadam and MS Joshi
}

DOI: https://doi.org/10.22271/chemi.2020.v8.i2g.8803

\begin{abstract}
Bacterial wilt of brinjal caused by Ralstonia solanacearum is responsible for severe yield losses (10$90 \%$ ) in farmer's field. A field experiment was conducted for the evaluation of different bio-agents, chemicals and plant extracts against bacterial wilt of brinjal at botany farm, DBSKKV, Dapoli during the Rabi, 2016-17 and 2017-18. The study revealed that all the treatments were significantly effective in controlling the disease. Seedling root dip in streptocycline @ $0.1 \%$ for 2 hrs. before transplanting was the most effective against the disease as it was recorded 50.63 percent disease reduction as compared to untreated and was followed by spot drenching of Pseudomonas fluorescens suspension $0.3 \%$ at the time of field preparation which recorded 48.10 percent disease reduction. Seedling root dip in bleaching powder solution $(0.1 \%)$ for 2 hrs. before transplanting recorded 45.57 percent disease reduction as compared to untreated and it was at par with $P$. fluorescens treatment.
\end{abstract}

Keywords: Bacterial wilt, Pseudomonas, streptocycline, bleaching powder

\section{Introduction}

The Brinjal, Aubergine or Eggplant (Solanum melongena L.), of the family solanaceae, is grown in the subtropical and tropical regions of the world. It is one of the most common, highly productive and popular vegetable crops grown in India. It is quite popular as the poor man's crop. The unripe fruit of eggplant is primarily used as a cooking vegetable for the various dishes in India and China. The brinjal is also reported to possess medicinal properties. Various plant parts are used for curing ailments such as diabetes, cholera, bronchitis, dysuria, dysentery, otitis, toothache, skin infections, asthenia and haemorrhoids. The major constraint, however, in the production of brinjal is the bacterial wilt disease.

India is the second largest country in the world producing brinjal followed by China. In India, the total area under brinjal was 669 thousand hectares with production of 12,400 thousand MT and with productivity of $18.9 \mathrm{MT} /$ ha during 2016-17. In Maharashtra, area under brinjal was 22.14 thousand hectares with annual production of about 433.28 thousand MT and with a productivity of 19.57 MT/ha. during 2016-17 (Anonymous, 2017) ${ }^{[2]}$. In Maharashtra, Pune is the leading brinjal growing district with 3.59 thousand hectares area and production of 71.80 thousand MT. Total area under brinjal in Konkan region of Maharashtra was 1.21 thousand ha. with production of 20.02 thousand MT and productivity of $16.54 \mathrm{MT} / \mathrm{ha}$. during the year 201617 (Anonymous, 2018) ${ }^{[3]}$.

The bacterial wilt disease caused by Ralstonia solanacearum is primarily a soil borne disease of wide distribution in the tropics, subtropics and warm temperate regions of the world. Bacterial wilt is said to be causing 10 to $90 \%$ crop losses around the world (Rao, 1976) ${ }^{[12]}$. In India, the disease is highly devastating and causes losses up to 80-90\% (Kishun, 1985 and Kataky et al., 2017) ${ }^{[8]}$. Sick soil and surface water, including irrigation water, are the primary sources of inoculum. The pathogen infects roots of susceptible plants usually through wounds (Pradhanang et al., 2005) ${ }^{[11]}$. Bacterial colonization in xylem tissues of infected plants hinders upward movement of water. Initially there is drooping of leaves which subsequently results in wilting of whole plants within 2-3 days and finally death of the whole plant.

Ralstonia solanacearum is a soil borne, rod shaped, Gram negative bacterium that causes bacterial wilt disease in more than 200 plant species including many economically important crops (Aliye et al. 2008) ${ }^{[1]}$. Due to its wide geographic distribution and unusually broad host range (over 50 plant families) the pathogen is responsible for severe crops losses worldwide. 
The disease is difficult to control. Although various control measures have been documented, bacterial wilt is still a major threat to brinjal production, because of wide host range of the pathogen and better survival of the pathogen in soil, especially in deeper layers. Thus, it is essential to acquire more knowledge for the effective control of this disease. The present investigation was designed to determine the appropriate control management of bacterial wilt by using different spot application treatment in soil as well as seedling dip root treatment with bio-control agents, chemicals, antibiotics and plant extracts under field conditions.

\section{Material and Methods}

The present investigation was carried out during Rabi 201617 and 2017-18 in wilt sick plot at Botany Farm, College of
Agriculture, Dapoli, Dist. Ratnagiri. Wilt susceptible variety 'Kali Rawai' of brinjal was used in this experiment. The experimental was set up by transplanting 30 days old seedlings in bacterial wilt sick plot using Randomized Block Design (RBD) of three replicates to compare 11 treatments (including control). Transplanting was made in $2.40 \times 3 \mathrm{~m}$ plots with $60 \times 60 \mathrm{~cm}$ spacing. All the recommended package of practices was followed during whole cropping season. The number of plants wilted per plot was recorded starting from 60 days after transplanting and then at 15 days intervals. Bacterial ooze test was performed for the wilted plants to confirm the disease. Details of the treatments are as follows;

Treatment details

\begin{tabular}{|c|c|}
\hline Treat. No. & Treatment Details \\
\hline $\mathrm{T}_{1}$ & Seedling root dip in $0.1 \%$ Asafoetida powder solution for 2 hrs. before transplanting. \\
\hline $\mathrm{T}_{2}$ & $\begin{array}{c}\text { Seedling root dip in bleaching powder solution }(0.1 \%) \text { for } 2 \text { hrs. before transplanting and spot application at the time of } \\
\text { field preparation @ } 0.3 \% \text {. }\end{array}$ \\
\hline $\mathrm{T}_{3}$ & Spot drenching of $P$. fluorescens suspension $0.3 \%$ at the time of field preparation. \\
\hline $\mathrm{T}_{4}$ & Seedling root dip in $10 \%$ soapnut extract for 2 hrs. before transplanting. \\
\hline $\mathrm{T}_{5}$ & Spot application of fish manure $100 \mathrm{~g}$ per plant at the time of transplanting. \\
\hline $\mathrm{T}_{6}$ & Spot application of lime $50 \mathrm{~g}$ per hill at the time of transplanting. \\
\hline $\mathrm{T}_{7}$ & $\begin{array}{c}\text { Seedling root dip in Azotobacter chroococcum }(0.1 \%) \text { for } 2 \text { hrs. before transplanting and spot application } 0.1 \% \text { at the time } \\
\text { of field preparation. }\end{array}$ \\
\hline $\mathrm{T}_{8}$ & Seedling root dip in streptocycline @ $0.1 \%$ for 2 hrs. before transplanting. \\
\hline $\mathrm{T}_{9}$ & Seedling root dip in chloramphenicol @ $0.1 \%$ for 2 hrs. before transplanting. \\
\hline $\mathrm{T}_{10}$ & Seedling root dip in Justicia adhatoda leaf extract @ 10\% for 2 hrs. before transplanting \\
\hline $\mathrm{T}_{11}$ & Control \\
\hline
\end{tabular}

\section{Method of recording observations}

Observations regarding wilt disease were recorded at fortnight interval 60 days after transplanting up to the 105 DAT, by counting the number of plants affected by the disease. Percent disease incidence was calculated using the following formula.

Total number of plants infected in the plot Percent disease incidence (PDI) $=\longrightarrow$ X 100 Total number of plants in the plot

Percent disease control was computed by formula (PDC): X

PDI in control - PDI in treatment Percent disease control as compared to control (PDC) $\longrightarrow$ X 100 PDI in control

\section{Results and Discussion \\ Percent disease intensity}

During Rabi 2016-17, results (Table 1) revealed that the terminal percent disease intensity was ranged between 33.33 to 68.33 percent. The lowest percent disease intensity was recorded in the treatment $\mathrm{T}_{8}$ (seedling root dip in streptocycline @ $0.1 \%$ for 2 hrs. before transplanting) $33.33 \%$ and was statistically at par with treatments $\mathrm{T}_{3}$ (spot drenching of Pseudomonas fluorescens suspension $0.3 \%$ at the time of field preparation) which recorded PDI to the tune of $35.00 \%$, Further, the treatment $\mathrm{T}_{3}$ was statistically at par with $\mathrm{T}_{2}$ (seedling root dip in bleaching powder solution (0.1\%) for 2 hrs. before transplanting and spot application at the time of field preparation @ 0.3\%) with $36.67 \%$ PDI. Rest of the treatments were also statistically significant over control.

\section{Percent disease control compared to untreated}

During Rabi, 2016-17 (Table 1) reduction in wilt disease intensity due to different treatments was ranged between 12.20 to 51.22 percent. The highest percentage disease control over control by $51.22 \%$ was observed in treatment $\mathrm{T}_{8}$ (seedling root dip in streptocycline @ $0.1 \%$ for 2 hrs before transplanting) and $48.78 \%$ in treatment $\mathrm{T}_{3}$ (spot drenching of Pseudomonas fluorescens suspension $0.3 \%$ at the time of field preparation) was followed by $\mathrm{T}_{2}(48.78 \%), \mathrm{T}_{9}(39.02 \%)$ and $\mathrm{T}_{4}(31.71 \%)$. Moderate reduction in disease over control was recorded in $\mathrm{T}_{6}(24.39 \%), \mathrm{T}_{5}(19.51 \%)$ and $\mathrm{T}_{1}(12.20 \%)$. Least PDC was recorded in $\mathrm{T}_{7}$ (seedling root dip in Azotobacter chroococcum for $2 \mathrm{hrs}$. before transplanting and application during field preparation @ $0.1 \%$ ) and $\mathrm{T}_{10}$ (seedling root dip in Justicia adhatoda leaf extract @ 10\% for 2 hrs. before transplanting) with 7.32 and 4.88 percent disease control over control, respectively.

\section{Percent disease intensity}

In the Rabi season of 2017-18 (Table 1) the overall percent disease intensity in wilt sick plot ranged between 31.67 to 63.33 percent. The maximum disease intensity was 5 percent lower than the previous year. The treatment $\mathrm{T}_{8}$ (seedling root dip in streptocycline @ $0.1 \%$ for 2 hrs. before transplanting) recorded 31.67 percent disease intensity and was numerically superior to rest of the treatments but statistically at par with $\mathrm{T}_{3}$ (spot drenching of Pseudomonas fluorescens suspension $0.3 \%$ at the time of field preparation) with 33.33 percent. The treatment $\mathrm{T}_{3}$ was at par with $\mathrm{T}_{2}$ (seedling root dip in bleaching powder solution $(0.1 \%)$ for $2 \mathrm{hrs}$. before transplanting and spot application at the time of field preparation @ 0.3\%) 35.00 percent. The treatment $\mathrm{T}_{7}$ (seedling root dip in 
Azotobacter chroococcum for 2 hrs before transplanting and spot application $0.1 \%$ at the time of field preparation) was at par with $\mathrm{T}_{10}$ (seedling root dip in Justicia adhatoda leaf extract @ $10 \%$ for 2 hrs. before transplanting).

\section{Percent disease control compared to untreated}

During Rabi, 2017-18 (Table 1) reduction in wilt disease intensity due to various different treatments was ranged between 7.89 to 50.00 percent. The highest percentage of disease control over control by $50.00 \%$ was observed in treatment $\mathrm{T}_{8}$ (seedling root dip in streptocycline @ $0.1 \%$ for 2 hrs. before transplanting) and was followed by $\mathrm{T}_{3}(47.37 \%)$, $\mathrm{T}_{2}(44.74 \%)$. Medium reduction in disease over control was recorded in $\mathrm{T}_{9}(36.84 \%), \mathrm{T}_{4}(28.95 \%), \mathrm{T}_{6}(23.68 \%)$. These were followed by $\mathrm{T}_{5}(18.42 \%)$ and $\mathrm{T}_{1}(13.16 \%)$. Least PDC was recorded in $\mathrm{T}_{7}$ and $\mathrm{T}_{10}$ with $(7.89 \%)$ and $(5.26 \%)$ percent disease control over control, respectively.

\section{Percent disease intensity (Pooled)}

The pooled analysis (Table 1) on percent disease intensity revealed that all the bio-agents, chemicals and plant extracts evaluated were found significantly effective against bacterial wilt of brinjal under wilt sick conditions in the field. Among all the treatments, antibiotic (streptocycline) were found most effective against the disease and were followed by bio-agents (P. fluorescens). Least percent disease intensity was observed in treatment $\mathrm{T}_{8}$ (seedling root dip in streptocycline @ $0.1 \%$ for $2 \mathrm{hrs}$. before transplanting) which showed 32.50 percent disease intensity as compared to control (65.83\%). This was followed by $\mathrm{T}_{3}$ (spot drenching of Pseudomonas fluorescens suspension $0.3 \%$ at the time of field preparation) and $\mathrm{T}_{2}$ (seedling root dip in bleaching powder solution $(0.1 \%)$ for 2 hrs. before transplanting and spot application at the time of field preparation@ @ 0.3\%) with 34.17 and 35.83 percent disease intensity, respectively and which were at par with each other. Treatment $\mathrm{T}_{9}$ (seedling root dip in chloramphenicol @ $0.1 \%$ for 2 hrs before transplanting), $\mathrm{T}_{4}$ (seedling root dip in 10\% soapnut extract for $2 \mathrm{hrs}$ before transplanting), $\mathrm{T}_{6}$ (spot application of lime $50 \mathrm{~g}$ per hill at the time of transplanting) and $\mathrm{T}_{5}$ (spot application of fish manure $100 \mathrm{~g}$ per plant at the time of transplanting) recorded 40.83 , $45.83,50.00$ and 53.33 percent disease intensity as against control. In the treatment $\mathrm{T}_{1}$ (seedling root dip in $0.1 \%$ asafoetida powder solution for 2 hrs before transplanting) and $\mathrm{T}_{7}$ (seedling root dip in Azotobacter chroococcum for $2 \mathrm{hrs}$. before transplanting and spot application $0.1 \%$ at the time of field preparation) recorded 57.50 and 60.83 percent disease intensity. Least percent disease intensity was observed in treatment $\mathrm{T}_{10}$ (seedling root dip in Justicia adhatoda leaf extract@10\% for 2 hrs before transplanting) 62.50\% as compared to control $(65.83 \%)$.

\section{Percent disease control compared to untreated (Pooled)}

Data (Table 1) also revealed that all the bio-agents, chemicals and plant extracts were effective in the bacterial wilt disease under field conditions. All the treatments were found significantly superior as compared to control. Highest percent disease control compared to control by $50.63 \%$ was recorded in treatment $\mathrm{T}_{8}$ (seedling root dip in streptocycline @ $0.1 \%$ for 2 hrs. before transplanting). It was followed by $\mathrm{T}_{3}$ (spot drenching of Pseudomonas fluorescens suspension $0.3 \%$ at the time of field preparation) and $\mathrm{T}_{2}$ (seedling root dip in bleaching powder solution $(0.1 \%)$ for $2 \mathrm{hrs}$. before transplanting and spot application at the time of field preparation @ 0.3\%) with $48.10 \%$ and $45.57 \%$ disease control compared to untreated, respectively. Treatment $\mathrm{T}_{9}$ (seedling root dip in chloramphenicol @ $0.1 \%$ for 2 hrs. before transplanting), $\mathrm{T}_{4}$ (seedling root dip in $10 \%$ soapnut extract for 2 hrs. before transplanting), $\mathrm{T}_{6}$ (spot application of lime $50 \mathrm{~g}$ per hill at the time of transplanting) and $\mathrm{T}_{5}$ (spot application of fish manure $100 \mathrm{~g}$ per plant at the time of transplanting) which recorded 37.96, 30.38, 24.05 and 18.99 percent disease reduction. In the treatment $\mathrm{T}_{1}$ (seedling root dip in $0.1 \%$ asafoetida powder solution for 2 hrs. before transplanting) and $\mathrm{T}_{7}$ (seedling root dip in Azotobacter chroococcum for $2 \mathrm{hrs}$. before transplanting and spot application $0.1 \%$ at the time of field preparation) recorded 12.66 and 7.59 percent disease reduction. Least percent disease reduction was observed in treatment $\mathrm{T}_{10}$ (seedling root dip in Justicia adhatoda leaf extract @ 10\% for 2 hrs. before transplanting) $5.06 \%$.

The findings are in close agreement with those of Dhital et al. (1997) ${ }^{[7]}$, according to them stable bleaching powder @ $25 \mathrm{~kg} / \mathrm{ha}$ was effective against $R$. solanacearum of potato. Biswas and Singh (2007) ${ }^{[5]}$ reported that soil disinfection with lime one month before transplantation and the use of $P$. fluorescens as bio-control agent were effective to minimize the bacterial wilt incidence in field. Baura and Bora (2008) found that highest reduction of bacterial population in soil was recorded in P. fluorescens when applied @ $15 \mathrm{~g} / \mathrm{kg}$ soil. Similarly, Chakravarty and Kalita (2012) ${ }^{[6]}$ reported that $P$. fluorescens had potential to be used as a biocontrol agent for the management of bacterial wilt of brinjal by application of antagonist suspension to seed+root+soil method and root+soil method. Ghosh et al. (2015) ${ }^{[10]}$ reported that application of bleaching powder $(20 \mathrm{~kg} / \mathrm{ha}$.) followed by lime $(500 \mathrm{~kg} / \mathrm{ha}$.), one month before transplanting, were most effective.

\section{Conclusion}

All the bio-agents, chemicals and plant extracts evaluated were found significantly effective against bacterial wilt of brinjal under wilt sick conditions in the field. Among all the treatments, seedling root dip in streptocycline @ $0.1 \%$ for 2 hrs. before transplanting was the most effective against the disease as it recorded 50.63 percent disease reduction compared to untreated. It was followed by spot drenching of Pseudomonas fluorescens suspension $0.3 \%$ at the time of field preparation which recorded 48.10 percent disease control. Seedling root dip in bleaching powder solution $(0.1 \%)$ for 2 hrs. before transplanting recorded 45.57 percent control and it was at par with $P$. fluorescens treatment. 
Table 1: Management of bacterial wilt of brinjal with use of bio-agents, chemicals and plant extracts

\begin{tabular}{|c|c|c|c|c|c|c|c|}
\hline \multirow[b]{2}{*}{$\begin{array}{l}\text { Tr. } \\
\text { No. }\end{array}$} & \multirow[b]{2}{*}{ Treatments } & \multicolumn{2}{|c|}{ Rabi, 2016-17 } & \multicolumn{2}{|c|}{ Rabi, 2017-18 } & \multicolumn{2}{|c|}{ Pooled } \\
\hline & & \begin{tabular}{|} 
Percent \\
Disease \\
Intensity \\
(PDI)* \\
\end{tabular} & $\begin{array}{c}\text { Percent } \\
\text { disease control } \\
\text { compared to } \\
\text { untreated }\end{array}$ & $\begin{array}{l}\text { Percent } \\
\text { Disease } \\
\text { Intensity } \\
\text { (PDI)* }\end{array}$ & \begin{tabular}{|c|} 
Percent \\
disease control \\
compared to \\
untreated
\end{tabular} & $\begin{array}{l}\text { Percent } \\
\text { Disease } \\
\text { Intensity } \\
\text { (PDI)* }\end{array}$ & \begin{tabular}{|c|}
$\begin{array}{c}\text { Percent disease } \\
\text { control } \\
\text { compared to } \\
\text { untreated }\end{array}$ \\
\end{tabular} \\
\hline $\mathrm{T}_{1}$ & $\begin{array}{l}\text { Seedling root dip in } 0.1 \% \text { asafoetida powder } \\
\text { solution for } 2 \mathrm{hrs} \text {. before transplanting. }\end{array}$ & $\begin{array}{c}60.00 \\
(50.79) * * \\
\end{array}$ & 12.20 & $\begin{array}{c}55.00 \\
(47.88) \\
\end{array}$ & 13.16 & $\begin{array}{c}57.50 \\
(49.33) \\
\end{array}$ & 12.66 \\
\hline $\mathrm{T}_{2}$ & $\begin{array}{c}\text { Seedling root dip in bleaching powder solution } \\
(0.1 \%) \text { for } 2 \text { hrs. before transplanting and spot } \\
\text { application at the time of field preparation @ } \\
0.3 \% \text {. }\end{array}$ & $\begin{array}{c}36.67 \\
(37.26)\end{array}$ & 46.34 & $\begin{array}{c}35.00 \\
(36.27)\end{array}$ & 44.74 & $\begin{array}{c}35.83 \\
(36.76)\end{array}$ & 45.57 \\
\hline $\mathrm{T}_{3}$ & $\begin{array}{c}\text { Spot drenching of Pseudomonas fluorescens } \\
\text { suspension } 0.3 \% \text { at the time of field preparation. }\end{array}$ & $\begin{array}{c}35.00 \\
(36.27) \\
\end{array}$ & 48.78 & $\begin{array}{c}33.33 \\
(35.25) \\
\end{array}$ & 47.37 & $\begin{array}{c}34.17 \\
(35.76) \\
\end{array}$ & 48.10 \\
\hline $\mathrm{T}_{4}$ & $\begin{array}{c}\text { Seedling root dip in } 10 \% \text { soapnut extract for } 2 \mathrm{hrs} . \\
\text { before transplanting. }\end{array}$ & $\begin{array}{c}46.67 \\
(43.09)\end{array}$ & 31.71 & $\begin{array}{l}45.00 \\
(42.13)\end{array}$ & 28.95 & $\begin{array}{c}45.83 \\
(42.61)\end{array}$ & 30.38 \\
\hline $\mathrm{T}_{5}$ & $\begin{array}{c}\text { Spot application of fish manure } 100 \mathrm{~g} \text { per plant at } \\
\text { the time of transplanting. }\end{array}$ & $\begin{array}{c}55.00 \\
(47.87) \\
\end{array}$ & 19.51 & $\begin{array}{c}51.67 \\
(45.96) \\
\end{array}$ & 18.42 & $\begin{array}{c}53.33 \\
(46.91) \\
\end{array}$ & 18.99 \\
\hline $\mathrm{T}_{6}$ & $\begin{array}{l}\text { Spot application of lime } 50 \mathrm{~g} \text { per hill at the time of } \\
\text { transplanting. }\end{array}$ & $\begin{array}{c}51.67 \\
(45.96)\end{array}$ & 24.39 & $\begin{array}{c}48.33 \\
(44.04)\end{array}$ & 23.68 & $\begin{array}{c}50.00 \\
(45.00)\end{array}$ & 24.05 \\
\hline $\mathrm{T}_{7}$ & $\begin{array}{l}\text { Seedling root dip in Azotobacter chroococcum } \\
(0.1 \%) \text { for } 2 \mathrm{hrs} \text {. before transplanting and spot } \\
\text { application } 0.1 \% \text { at the time of field preparation. }\end{array}$ & $\begin{array}{c}63.33 \\
(52.74)\end{array}$ & 7.32 & $\begin{array}{c}58.33 \\
(49.80)\end{array}$ & 7.89 & $\begin{array}{c}60.83 \\
(51.27)\end{array}$ & 7.59 \\
\hline $\mathrm{T}_{8}$ & $\begin{array}{c}\text { Seedling root dip in streptocycline @ } 0.1 \% \text { for } 2 \\
\text { hrs. before transplanting. }\end{array}$ & $\begin{array}{c}33.33 \\
(35.25)\end{array}$ & 51.22 & $\begin{array}{c}31.67 \\
(34.23)\end{array}$ & 50.00 & $\begin{array}{c}32.50 \\
(34.74)\end{array}$ & 50.63 \\
\hline $\mathrm{T}_{9}$ & $\begin{array}{c}\text { Seedling root dip in chloramphenicol @ } 0.1 \% \text { for } 2 \\
\text { hrs. before transplanting. }\end{array}$ & $\begin{array}{c}41.67 \\
(40.20) \\
\end{array}$ & 39.02 & $\begin{array}{c}40.00 \\
(39.21) \\
\end{array}$ & 36.84 & $\begin{array}{c}40.83 \\
(39.70) \\
\end{array}$ & 37.96 \\
\hline $\mathrm{T}_{10}$ & $\begin{array}{c}\text { Seedling root dip in Justicia adhatoda leaf extract } \\
\text { @ } 10 \% \text { for } 2 \text { hrs. before transplanting. }\end{array}$ & $\begin{array}{c}65.00 \\
(53.76) \\
\end{array}$ & 4.88 & $\begin{array}{c}60.00 \\
(50.77) \\
\end{array}$ & 5.26 & $\begin{array}{c}62.50 \\
(52.27) \\
\end{array}$ & 5.06 \\
\hline $\mathrm{T}_{11}$ & Control & $\begin{array}{c}68.33 \\
(55.77)\end{array}$ & - & $\begin{array}{c}63.33 \\
(52.74)\end{array}$ & - & $\begin{array}{c}65.83 \\
(54.26)\end{array}$ & - \\
\hline & S. Em \pm & 0.97 & & 1.02 & & 0.81 & \\
\hline & C. $\mathrm{D}$ at $5 \%$ & 2.86 & & 3.00 & & 2.38 & \\
\hline
\end{tabular}

*Mean of three replications ** Values in parentheses are arc-sin transformed values

\section{References}

1. Aliye N, Fininsa C, Hiskias Y. Evaluation of rhizosphere bacterial antagonists for their potential to bioprotect potato (Solanum tuberosum) against bacterial wilt (Ralstonia solanacearum). Biological Control. 2008; 47:282-288.

2. Anonymous. Horticultural Statistics at a Glance 2017. Horticulture Statistics Division, Department of Agriculture, Cooperation and Farmers Welfare, Ministry of Agriculture and Farmers Welfare, Government of India, 2017, 1-481. www.agricoop.nic.in,

3. Anonymous. Hoticulture Area Production Information System (HAPIS), 2018.

4. Baura L, Bora BC. Comparative efficacy of Trichoderma harzianum and Pseudomonas fluorescens against Meloidogyne incognita and Ralstonia solanacearum complex in brinjal. Indian $\mathbf{J}$ of nematology. 2008; 38(1):86-89.

5. Biswas S, Singh NP, Effect of host genotypes and cultural practices for the management of bacterial wilt in brinjal (Solanum melongena L.). Indian Phytopath. 2007; 60(4):438-441.

6. Chakravarty G, Kalita MC. Biocontrol potential of Pseudomonas fluorescens against bacterial wilt of brinjal and its possible plant growth promoting effects. Annals of Biological Research. 2012; 3(11):5083-5094.

7. Dhital SP, Thaveechai N, Kositratana W, Piluek K, Shrestha SK. Effect of chemical and soil amendment for the control of bacterial wilt of potato in Nepal caused by Ralstonia solanacearum. Kasetsart J (Nat. Sci.). 1997; 31: 497-509.
8. Kataky M, Tamuli AK, Teron R, Sarma RK. Biochemical characterization of Ralstonia solanacearum causing bacterial wilt of brinjal in the hilly district of Assam. Int. J. Pure App. Biosci. 2017; 5(4):2147-2157.

9. Kishun R. Effect of bacterial wilt on yield of tomato. Indian Phytopathology. 1985; 38:606.

10. Ghosh PP, Dutta S, Chattopadhyay A. Integration of organic and inorganic amendments with native bioagents for bio-intensive management of vascular bacterial wilt on eggplant (Solanum melongena). Indian Phytopath. 2015; 68(1):32-38.

11. Pradhanang PM, Ji P, Momol MT, Olson SM, Mayfield JL, Jones JB. Application of acibenzolar-S-methyl enhances host resistance in tomato against Ralstonia solanacearum. Plant disease. 2005; 89:989-993.

12. Rao MVB. Bacterial wilt of tomato and eggplant in India. In: Proc. 1st Planning Conf. and Workshop on Ecology and Control of bacterial wilt caused by Pseudomonas solanacearum (Eds.) L. Sequerianad A. Kelman, North Carolina State Univ., Raleigh, 1976, 92-94. 